\title{
Tectonic-Related Geochemical and Hydrological Anomalies in Italy during the Last Fifty Years
}

\author{
Giovanni Martinelli ${ }^{1,2,3}{ }^{\oplus}$, Riccardo Ciolini ${ }^{4}\left(\mathbb{D}\right.$, Gianluca Facca ${ }^{5}$, Francesco Fazio ${ }^{6}$, Fabrizio Gherardi ${ }^{5, *}$, \\ Jens Heinicke ${ }^{7}$ and Lisa Pierotti ${ }^{5}$
}

check for

updates

Citation: Martinelli, G.; Ciolini, R.; Facca, G.; Fazio, F.; Gherardi, F.;

Heinicke, J.; Pierotti, L.

Tectonic-Related Geochemical and Hydrological Anomalies in Italy during the Last Fifty Years. Minerals 2021, 11, 107. https://doi.org/ $10.3390 / \min 11020107$

Academic Editors: Andrea Pozzi and Gilberto Binda

Received: 30 December 2020

Accepted: 19 January 2021

Published: 22 January 2021

Publisher's Note: MDPI stays neutral with regard to jurisdictional claims in published maps and institutional affiliations.

Copyright: (C) 2021 by the authors. Licensee MDPI, Basel, Switzerland. This article is an open access article distributed under the terms and conditions of the Creative Commons Attribution (CC BY) license (https:/ / creativecommons.org/licenses/by/ $4.0 /)$.
1 Istituto Nazionale di Geofisica e Vulcanologia (INGV), 90146 Palermo, Italy; giovanni.martinelli15@gmail.com 2 Institute of Eco-Environment and Resources, Chinese Academy of Sciences (CAS), Lanzhou 730000, China

3 Laboratory of Petroleum Resources Research, Institute of Geology and Geophysics, Chinese Academy of Sciences (CAS), Lanzhou 730000, China

4 Department of Civil and Industrial Engineering, Università di Pisa, 56122 Pisa, Italy; r.ciolini@ing.unipi.it

5 Consiglio Nazionale delle Ricerche (CNR), Istituto di Geoscienze e Georisorse (IGG), 56124 Pisa, Italy; gianluca.facca@igg.cnr.it (G.F.); lisa.pierotti@igg.cnr.it (L.P.)

6 GEODIXI, 95131 Catania, Italy; faziogeo@tiscali.it

7 Institute of Geophysics and Geoinformatics, TU Bergakademie, 09596 Freiberg, Germany; jens.heinicke@geophysik.tu-freiberg.de

* Correspondence: f.gherardi@igg.cnr.it

\begin{abstract}
Seismic hazard reduction policies usually utilize earthquake catalogues and probability evaluations of occurrence. Further geophysical and geochemical parameters could contribute to hazard reduction policies as is currently the case in some countries, such as Iceland, Taiwan, China and Russian Federation. In the past four decades, intense research activity carried out by many different institutions in Italy has allowed us to recognize the most relevant sensitive sites for detecting acceleration in crustal deformation processes by means of geofluids monitoring. All scientific papers published in the period 1976-2020 concerning tectonic-related signals in geofluids have been considered. An in-depth review of previous and present-day research activities, as well as an update of two unpublished time series recorded in Central and Southern Italy, has contributed to identifying areas where an instrumental array is still lacking and the most relevant priority areas for monitoring activities in geofluids. An atlas of all experimental sites utilized in recent decades has been obtained with the purpose of contributing to identifying the most suitable monitoring areas.
\end{abstract}

Keywords: geofluids; geochemical anomalies; hydrologic anomalies; earthquake precursors; seismic hazard mitigation; Italy

\section{Introduction}

The Probabilistic Seismic Hazard Assessment (PSHA) has become the most common and standardized procedure to address the seismic threat facing society. The PSHA aims to evaluate the probability that a ground motion intensity measure, e.g., the peak ground acceleration (PGA), will exceed a threshold level in a given period. A standard output of a PSHA is a map displaying the PGA level that has a $10 \%$ exceedance probability in 50 years (e.g., [1], and references therein). Due to this direct connection with seismic design codes, the PSHA has gained a central role in engineering applications, seismic risk analysis and the definition of the design basis ground-motions. PSHA methods are now recognized as the only reliable procedure able to allow, within certain limits, a significant seismic hazard mitigation [2]. Insights about future seismic activity may, in principle, also come from earthquake forecasting, which is based on the physical laws that relate physical or chemical parameters believed to be precursors of seismic events [3,4].

In particular, additional geophysical, hydrologic and geochemical parameters (e.g., [5]) have also been utilized in research oriented to earthquake forecasting ([6], and references therein). 
Hazard maps are still preferred by governmental authorities as a tool to mitigate earthquake risks, while other non-seismometric parameters are experienced in some test site areas where research about earthquake forecasting is carried out. Their use is limited to scientific institutions while the governments of Iceland, Taiwan, China and the Russian Federation (see also [7], for a review) utilize possible geophysical and geochemical precursors for civil defense purposes. Part of this supplementary research involves methods oriented to geofluids monitoring. In Italy, the PSHA was set up a few decades ago for building codes ([8], and references therein), while further improvements have recently been proposed by [9].

The monitoring of geofluids in the framework of earthquake forecasting research started from the mid-seventies, following pioneering activities carried out in China, Japan and in the former USSR $[10,11]$. The monitoring of hydrologic and geochemical parameters started with manual techniques in selected areas and slowly reached modern standards with present-day automatic equipment. These kinds of monitoring were also applied in Italy and were previously reviewed and commented by $[12,13]$. The purpose of this paper is to gather and comment on all available information about the monitored sites in Italy, and to summarize the most relevant results related to eventual pre-seismic anomalies recorded in published time series to highlight possible future research trends. Additional unpublished data from Sicilia and Campania regions are also presented.

\section{Monitored Areas and Recorded Data}

Many areas (Figure 1) have hosted experimental monitoring activities in geofluids oriented to geodynamic monitoring and to research about possible earthquake precursors. For the sake of the simplicity, information is reported for each Italian region as follows.
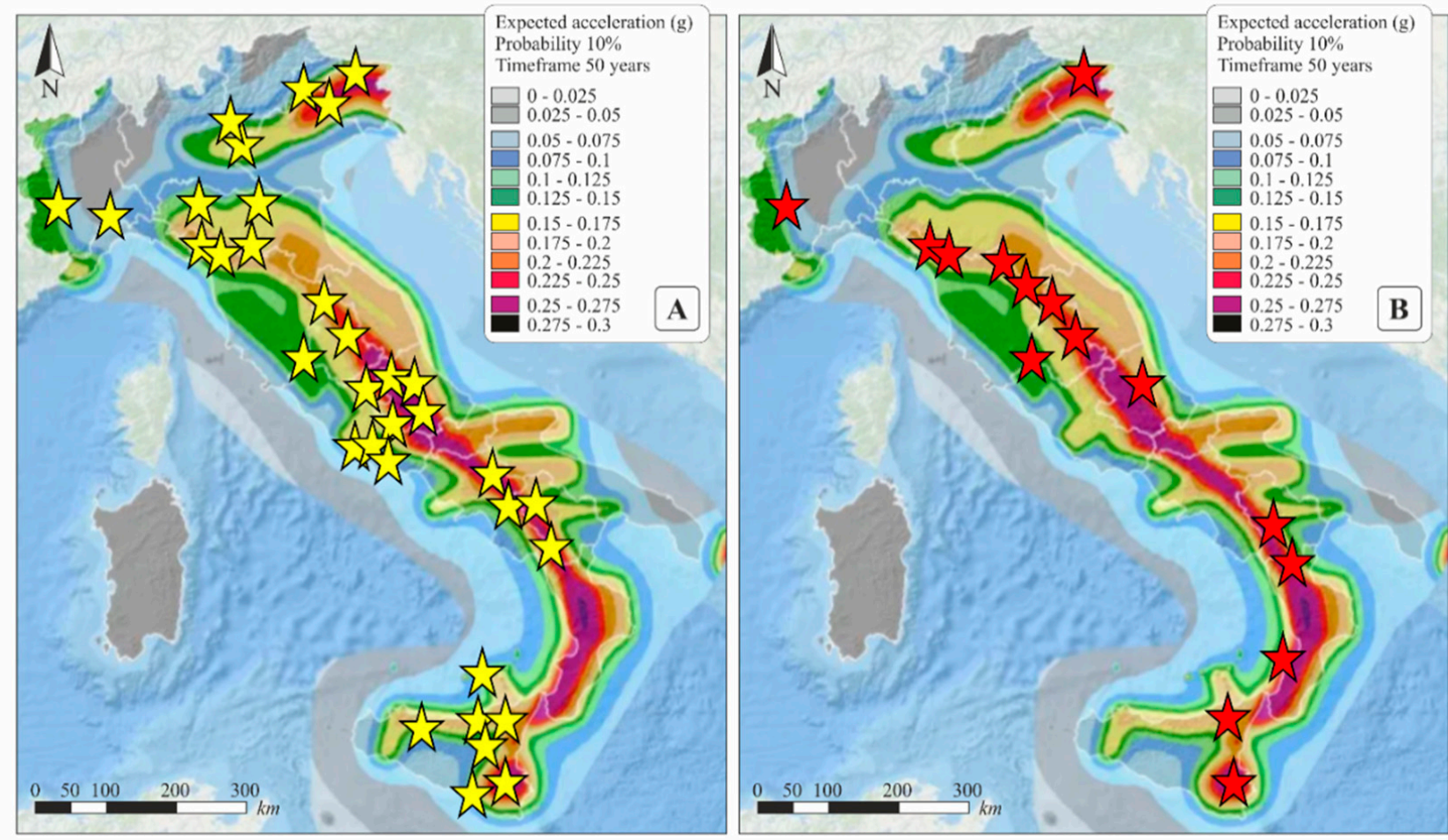

Figure 1. Seismic risk map for Italy (modified after http:/ / esse1-gis.mi.ingv.it/), along with the location of the monitoring sites in Italy where tectonic-related signals have been recorded during the last four decades. (A) Yellow stars: sites currently not monitored; (B) red stars: sites currently monitored. 


\subsection{Piemonte}

De Gregorio et al. [14] reported anomalous temperature variations recorded in waters of a shallow depth well in the area of Nizza Monferrato (Asti province), possibly due to local small seismic events. De Liso et al. ([15], and references therein) reported a radon time series which evidences a fluctuation possibly due to some small local earthquakes close to Pinerolo (Torino province).

\subsection{Lombardia}

Facchini et al. [16] reported geodynamically induced radon fluctuations in groundwater from a deep geothermal well located close to the town of Goito (Mantova province). Martinelli [17] attributed the observed fluctuations to possible crustal deformations due to small local seismic events. Balderer and Leuenberger [18] reported possible changes in the chemical composition of bottled mineral waters induced by local seismic events close to the town of Salò (Brescia province).

\subsection{Friuli Venezia Giulia}

Petrini et al. [19] reported geochemical anomalies in some groundwaters from the Udine province due to local seismic events and associated crustal deformation processes. Garavaglia et al. [20] and Riggio and Sancin ([21], and references therein) reported radon fluctuations in the groundwaters of the area of Arta Terme (Udine province) possibly linked to local crustal deformations. Rossi et al. [22] evidenced the role of groundwaters in stress diffusion processes detected in North-Eastern Italy by global navigation satellite systems.

\subsection{Emilia Romagna}

Albarello and Martinelli [23] observed piezometric variations linked neither to withdrawal nor to climate in wells monitored by the environmental protection agency of Emilia Romagna region (ARPAE) in the eastern side of the region (Forlì and Ravenna provinces). A possible relation with local crustal deformation processes was evidenced. Martinelli et al. [24] reported radon variations in mud-volcanic groundwaters in the Modena province observed in concomitance with a local seismic sequence. Heinicke et al. [25] evidenced fluctuations in the temperature and flow rate of groundwaters from a deep geothermal well in the Corniglio municipality (Parma province) in the Northern Apennines during a local seismic sequence. Fidani et al. [26] reported the possible effects of the Emilia seismic sequence on the chemical composition of bottled mineral waters from the provinces of Reggio Emilia, Modena and Bologna, on Northern Apennines.

\subsection{Toscana}

Heinicke et al. [27] reported flow rate data of a $\mathrm{CO}_{2}$ emission located in Caprese Michelangelo (Arezzo province) and highlighted the sensitivity of the $\mathrm{CO}_{2}$ flow rate to local seismic events. Cioni et al. [28] reported a significant increase in the dissolved $\mathrm{CO}_{2}$ content of the Equi thermal spring (Massa Carrara province) twelve days before an $M_{W}=3.7$ earthquake with an epicenter $3 \mathrm{~km}$ north of the monitoring site. Pierotti et al. [29] reported data about dissolved $\mathrm{CO}_{2}$ in the thermal waters of the Gallicano spring (Lucca province) and evidenced that possible anomalous signals were recorded before, during and after two significant seismic events that occurred in Garfagnana in 2013 (Figure 2). Pierotti et al. [30] showed a sudden increase in $\mathrm{CO}_{2}$ concentration in the Bagnore thermal spring, located in proximity of the intersection of two major fault systems of Mt Amiata (Grosseto province). This trend has been interpreted as an evidence for an enhanced inflow of deep, possibly geothermal gases $\left(\mathrm{CO}_{2}, \mathrm{H}_{2} \mathrm{~S}\right.$ and water vapor) in the monitored aquifer associated with local seismic events. Gherardi and Pierotti [31] reported time series of dissolved $\mathrm{CO}_{2}$ and $\mathrm{CH}_{4}$ in thermal waters of Pieve Fosciana (Lucca province). The recorded data are sensitive to earth tides, suggesting the suitability of the site for detecting possible gas flux variations induced by crustal deformation processes. 

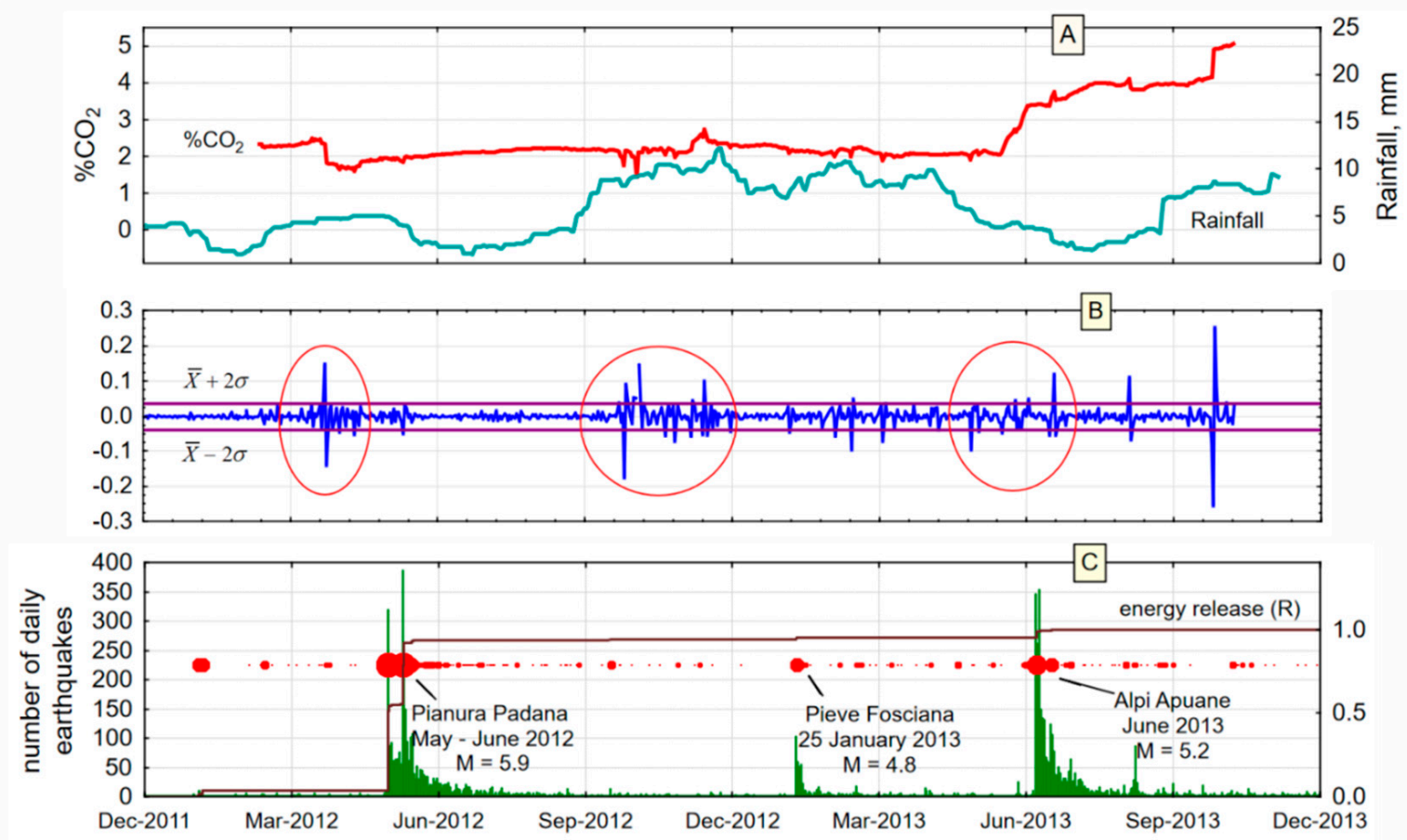

Figure 2. Time series for the Gallicano thermomineral spring (after [29]. (A) Aqueous $\% \mathrm{CO}_{2}$ and three-month rain moving average signals (rainfall data from https:/ / www.sir.toscana.it/) during the February 2012 to October 2013 period; (B) irregular component of $\% \mathrm{CO}_{2}$ signal (processed with Census I method [32]). Anomalies are encircled by red ellipses; (C) seismic activity: green bars-number of daily earthquakes; red dots-seismic events with radius proportional to the magnitude; brown line-normalized cumulative curve of energy release calculated according to the relation $\log E=1.5 \times M_{L}+11.8$ [33] Seismic information from the Italian Seismological Instrumental and parametric Database (ISIDe: http://iside.rm.ingv.it).

\subsection{Umbria}

Italiano et al. [34-36] and Caracausi et al. [37] reported geochemical variations in three gaseous emissions (Montecastello di Vibio, Umbertide and Massa Martana municipalities, Perugia province) and in three thermal springs (Triponzo, Parrano and Stifone villages, Perugia province) due to crustal deformations associated with the Central Italy seismic sequence of 2009. By monitoring a geothermal well located near the Triponzo village, Lapenna et al. [38] reported variations in water level, temperature, electric conductivity and $\mathrm{pH}$ possibly linked to crustal deformation processes associated with the 1997-1998 Central Italy seismic sequence. Quattrocchi et al. [39] reported geochemical variations in the thermal spring of Triponzo induced by the 1997-1998 Central Italy seismic sequence. Heinicke et al. [40] reported flow rate variations in a $\mathrm{CO}_{2}$ gas emission in the Massa Martana municipality (Perugia province) in concomitance with the Central Italy seismic swarm of 2009, and with a number of lower energy seismic events occurring locally during the period 2005-2008.

\subsection{Marche}

Dadomo et al. [41] reported water level, electric conductivity and temperature variations recorded in the Acquasanta thermal springs (Ascoli Piceno province). Anomalies were observed during the Central Italy seismic swarm of 2009.

\subsection{Abruzzo}

Plastino et al. [42] recorded geochemical anomalies in groundwaters from the Gran Sasso area during the Central Italy seismic sequence of 2009. Barberio et al. [43] recorded geochemical variations in groundwaters of the Gran Sasso area during the Central Italy seismic sequence of 2016. The observed anomalies were induced by deep originated $\mathrm{CO}_{2}$ 
squeezed toward the surface by crustal deformation processes. De Luca et al. [44] recorded pressure variations in groundwaters of the Gran Sasso area during the Central Italy seismic sequence of 2016. The recorded anomalies were probably induced by crustal deformation processes. Similar conclusions were reached by [45] utilizing satellite and ground-based geochemical data to investigate a number of springs and wells in a wide area of Abruzzo region (Figure 3).

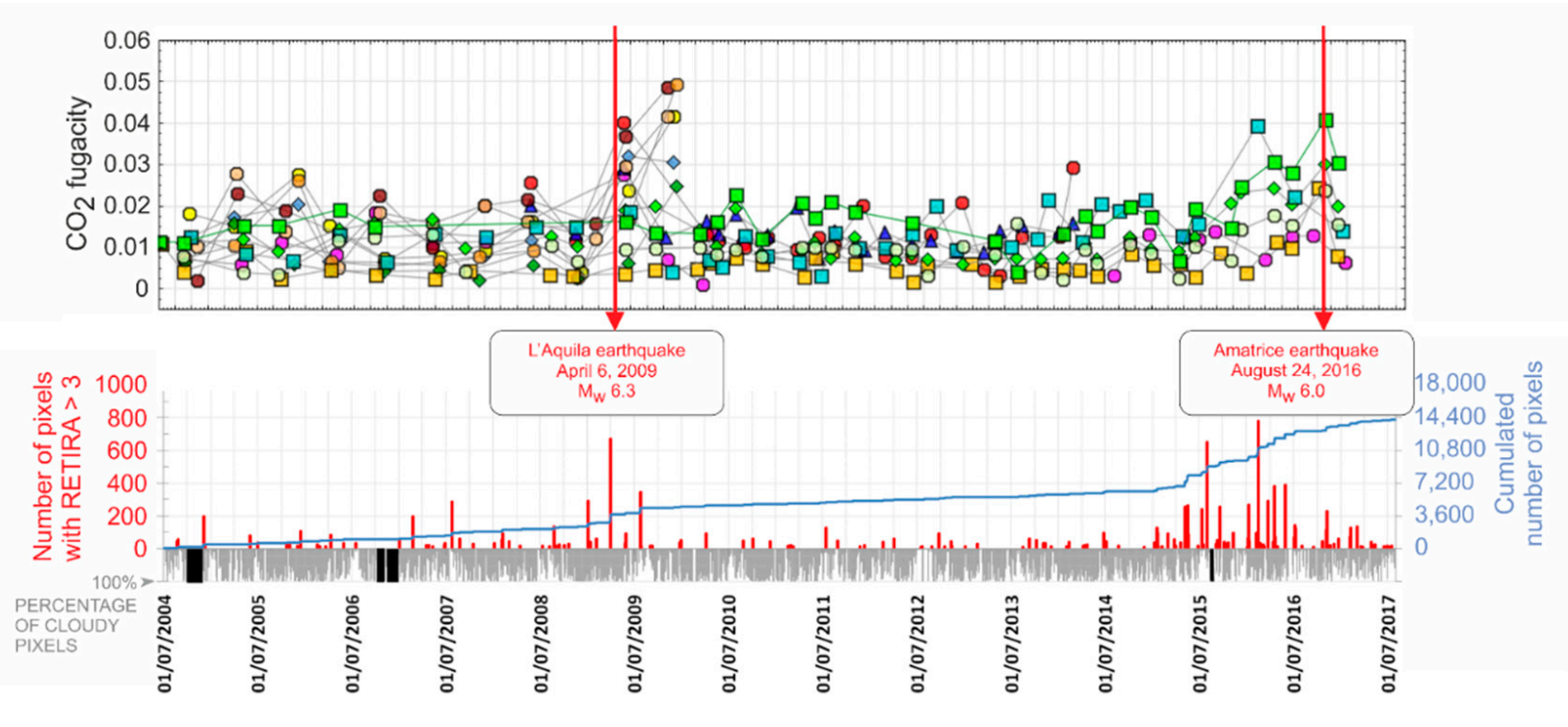

Figure 3. Tectonic-related anomalous values of $\mathrm{CO}_{2}$ fugacity in water samples from the environmental protection agency (ARTA) network in Abruzzo (upper box), compared with thermal infrared radiation (TIR) anomalies from satellite data (lower box) (after [45]).

\subsection{Lazio}

Alessio et al. [46] recorded radon fluctuations in groundwaters of the Peschiera springs (Rieti province) before and during the Central Italy seismic sequence of 1979 (Umbria region). The recorded anomalies were confirmed by tiltmetric measurements, which evidenced the existence of local crustal deformation processes. Allegri et al. [47] recorded radon and tiltmetric fluctuations in a well located close to Mentana (Roma province) and in the Peschiera springs (Rieti province) before and during two seismic sequences that occurred in 1980 in Central Italy and in Southern Italy. Dall'Aglio et al. [48] recorded variations in the geochemical signature of the thermal waters of Acque Albule springs (Roma province). The observed variations occurred in concomitance with the Alban Hills seismic sequence of 1981. Lombardi et al. [49] recorded radon fluctuations in soil gas in the caldera of Latera (Viterbo province) possibly due to a local seismic swarm in the Vulsini Mountains. Quattrocchi and Calcara [50] recorded geochemical fluctuations in a water well close to Rocca di Papa (Roma province) in concomitance with a seismic swarm that occurred in the Alban Hills. By applying ground-based and satellite techniques, Martinelli et al. [45] observed a number of geochemical anomalies in a number of water points from the Rieti province possibly related to the L'Aquila and Amatrice seismic sequences of 2009 and 2016, respectively.

\subsection{Basilicata}

Di Bello et al. [51] reported gas flux and radon fluctuations recorded in a bubbling gas geothermal well in Val D'Agri (Potenza province). Colangelo et al. [52] reported gas flux variations recorded in the same well. The observed variations were connected to crustal deformation processes due to a local seismic swarm. Colangelo et al. [53] reported fluc- 
tuations observed in electric conductivity, temperature and flow rate recorded in thermal waters of the Pieschi spring and in a geothermal well in Val d'Agri (Potenza province). Further fluctuations were observed in other geophysical parameters and confirmed the link to local crustal deformation processes.

\subsection{Campania}

Ghiara et al. ([54], and references therein) reported geochemical, flow rate and temperature variations of the thermal waters discharged in the Contursi area (Salerno province) in concomitance with the 1980 seismic sequence. Molin et al. [55] reported anomalies in flow rate, temperature and chemical composition of hydrothermal emissions of Ischia Island (Napoli province) during seismic events that occurred in 1863, 1881 and 1883. Mongelli et al. [56] carried out heat flux measurements close to the epicentral area of the 23 November $1980 M_{W}=6.8$ earthquake in the Avellino province. In the same well intercepting a local $\mathrm{Ca}-\mathrm{HCO}_{3}$ aquifer, the piezometric level, temperature and chemical composition of the thermal water have been monitored. The sampled groundwater showed similar geochemical features compared to $\mathrm{Ca}-\mathrm{HCO}_{3}$ groundwaters predominantly occurring in the surrounding area (Figure 4; data after $[54,57,58]$ ). In particular, the high $\mathrm{HCO}_{3}$ concentration was ascribed to the strong $\mathrm{CO}_{2}$ degassing activity of local mofetes. A probe capable of continuously measuring the water level and temperature was placed in the well and recorded data are shown in Figure 5 (see also Table S1 of the Supplementary Material). Four relevant anomalous periods were identified. Three of them occurred during short local seismic sequences, while an unexplained anomalous period was recorded in MarchApril 2009.

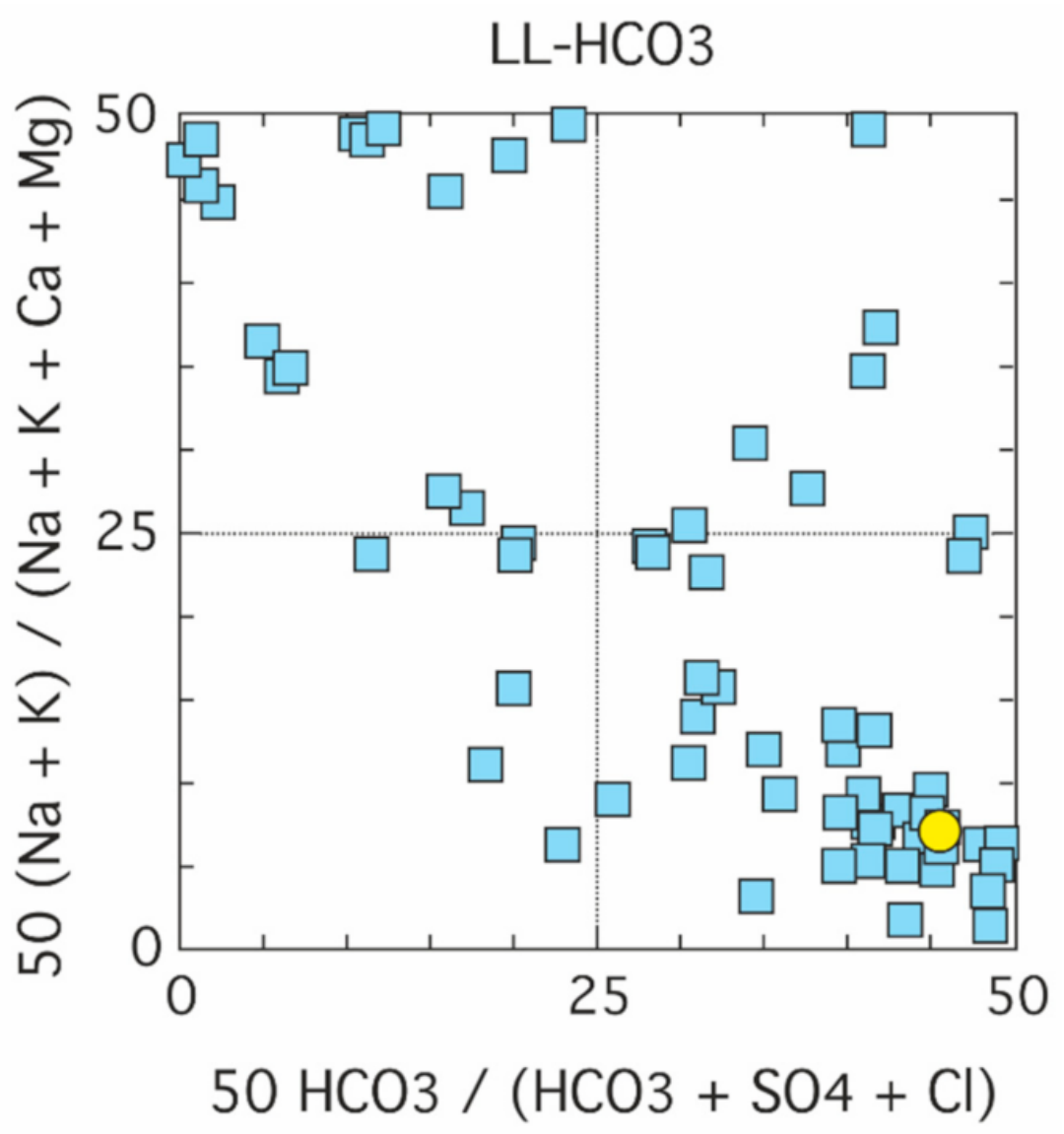

Figure 4. $\mathrm{LL}_{-} \mathrm{HCO}_{3}$ diagram [59] for selected groundwater samples from Campania region (blue squares data after [57]). The yellow dot represents water sampled in a well drilled near the Mefite d'Ansanto $\mathrm{CO}_{2}$ gas emission [56]. 

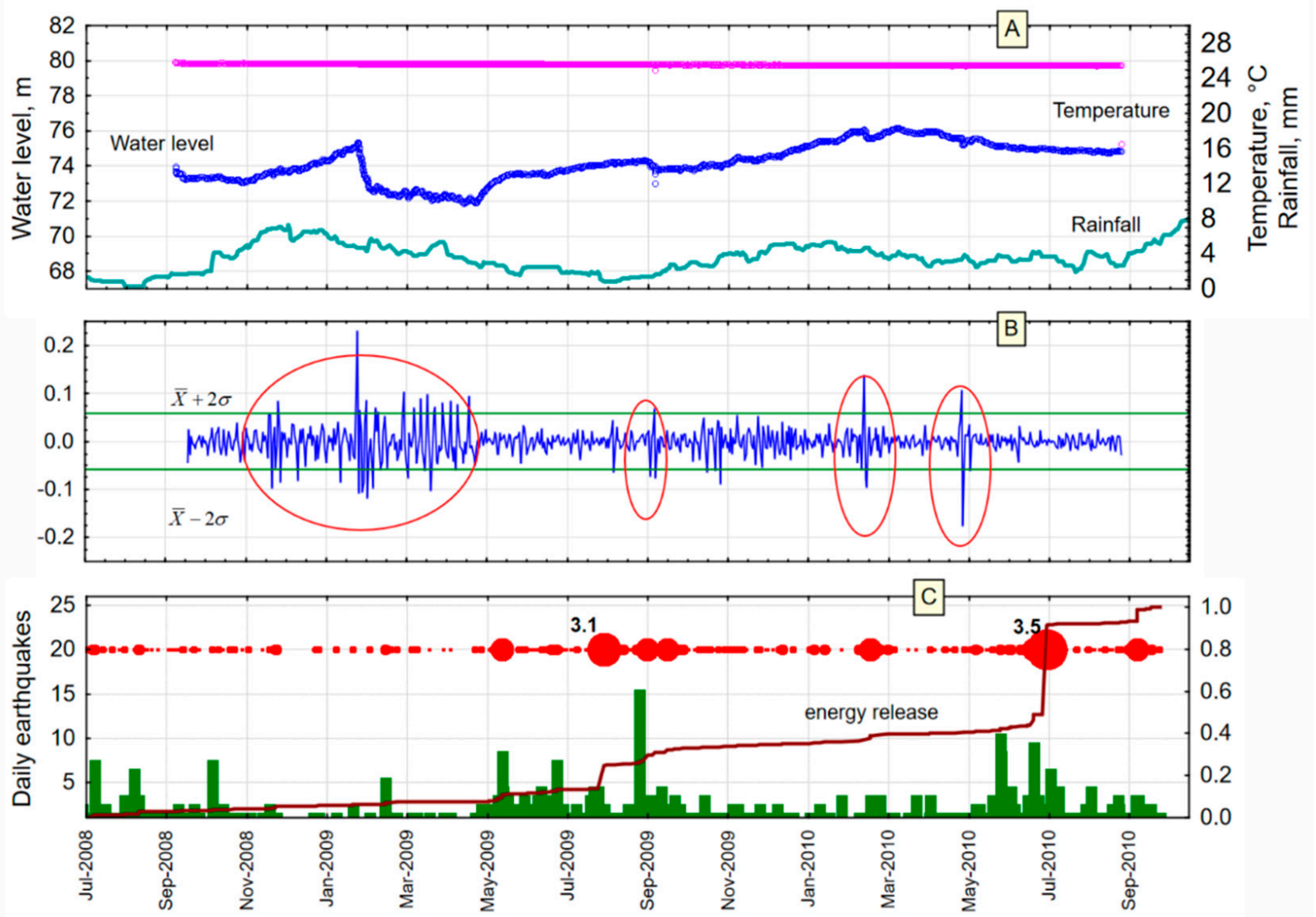

Figure 5. Water level recorded in the Mefite d'Ansanto (145 m depth) well during the September 2008 to September 2010 period. (A) Water level (m, left axis) and temperature (degrees Celsius, right axis) compared with the three-months rain moving average signal (rainfall data recorded in Sant'Angelo dei Lombardi pluviometric station-http:/ / www.agricoltura. regione.campania.it/meteo); (B) irregular component of water level signal (processed with Census I method [32]). Anomalies are encircled by red ellipses; (C) seismic activity: green bars-number of daily earthquakes; red dots-seismic events with radius proportional to the magnitude; brown line-normalized cumulative curve of energy release calculated according to the relation $\log E=1.5 \times M_{L}+11.8$ [33]. Seismic information from the Italian Seismological Instrumental and Parametric Database (ISIDe; http:/ / iside.rm.ingv.it).

\subsection{Sicilia}

Del Pezzo et al. [60] recorded radon anomalies in soil gases before a local seismic swarm in the island of Vulcano (Messina province). Quattrocchi et al. [61] recorded variations in temperature in a water well during a local seismic swarm close to Belpasso, on the slopes of the Mt. Etna (Catania province). Immè et al. [62] recorded variations in soil radon monitored in Piedimonte Etneo (Catania province) due to seismic events linked to volcanic activity of Mt. Etna. Cigolini et al. [63] recorded radon emissions in soil gases in Stromboli island (Messina province) before some significant local seismic events. Favara et al. [64] recorded fluctuations in geochemical parameters and flow rate of thermal springs in the Palermo province, possibly induced by crustal deformations associated to the Pollina seismic sequence of 1993. Camarda et al. [65] recorded fluctuations in $\mathrm{CO}_{2}$ flow rate in the provinces of Messina, Siracusa and Ragusa, possibly induced by local crustal deformations. Further hydrogeological and geochemical data were recorded during the period 1990-1993 during and after the $M_{W}=5.6\left(M_{L}=5.4\right)$ seismic event of 13 December 1990.

In particular, the water level of a $400 \mathrm{~m}$ deep well (E29 well) drilled close to Augusta (Siracusa province) was monitored by means of an automatic equipment. Groundwater drained by the E29 well has a meteoric origin and is hosted in a calcareous formation characterized by low circulation velocity. Most relevant geochemical and hydrogeological features 
of local groundwaters have been previously described by [66-68]. In particular, groundwaters sampled from wells in the area affected by most relevant effects of the $M_{W}=5.6$ seismic event belong to the $\mathrm{Na}-\mathrm{HCO}_{3}-\mathrm{Cl}$ group (Figure 6). A slight variation in the water level was observed two days before the mainshock (Figure 7), and the original water level was restored three days after mainshock (see also Table S2 of the Supplementary Material).

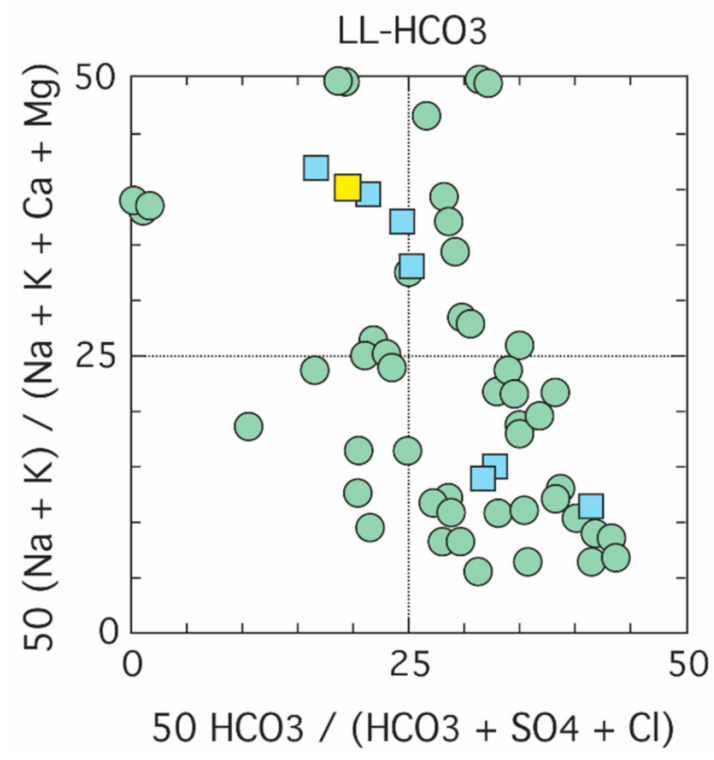

Figure 6. $\mathrm{LL}-\mathrm{HCO}_{3}$ diagram [59] for selected groundwater samples from Sicilia region (green dots, data after [66]; blue squares, data after [67]). The yellow square represents the chemical composition of E29 well groundwater.
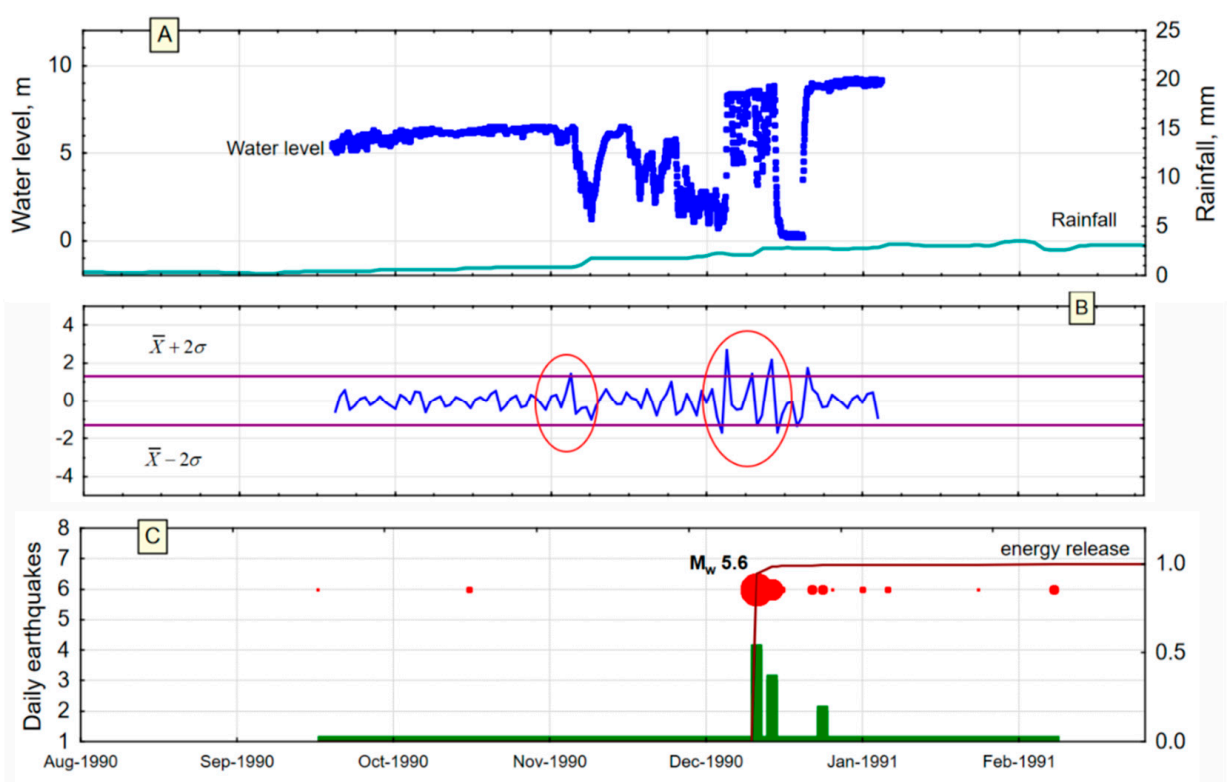

Figure 7. Tectonic-related anomalous signal of water level recorded in the E29 well. (A) Water level data recorded during the August 1990-February 1991 period; (B) irregular component of water level signal (processed with Census I method [32]). Anomalies are encircled by red ellipses; (C) seismic activity: green bars-number of daily earthquakes; red dots-seismic events with radius proportional to the magnitude; brown line-normalized cumulative curve of energy release calculated according to the relation $\log E=1.5 \times M_{L}+11.8$ [33]. Seismic information from [69] and the Italian Seismological Instrumental and Parametric Database (ISIDe; http:/ / iside.rm.ingv.it). 
To our knowledge, precursory signals in geofluids were not investigated and/or detected in the Trentino Alto Adige, Veneto, Valle D'Aosta, Liguria, Molise, Puglia, Calabria and Sardegna regions.

\section{Quality and Reliability of the Observed Data}

In principle, all datasets recorded to monitor precursory geofluids anomalies should be collected according to standard rules to guarantee, within some limitations, the reliability of the recorded datasets, and to possibly use them for decision-making. Roeloffs [70] and Kumpel [71] provided guidelines to reliably report on tectonic-related phenomena in geofluids, and possible earthquake precursors. In the same vein as that studies, there is a general recognition that the following information should accompany every report or publication about possible precursory phenomena in geofluids: (1) well depth/general features of the sampled manifestation; (2) rainfall record for at least one year; (3) record of barometric pressure; (4) information about wells being pumped in the same vicinity; (5) the longest record of observations should be shown; (6) measurement technique: pressure transducer, float recorder, tape soundings; (7) sampling interval; (8) response to earth tides; (9) co-seismic response of water level to the subsequent earthquake; (10) magnitude of the earthquake; (11) depth and focal mechanism of the earthquake; (12) times, magnitudes and hypocenters of any recorded foreshocks; (13) distance of azimuth of well from epicenter; (14) a graph of raw water level versus time during the anomaly; (15) description of any other wells in the vicinity that were monitored but did not show anomalies; (16) information on the geology of the site, particularly its proximity to any fault zones is also useful; (17) some assessment should be given as to whether the reservoir is confined.

The above checklist was extended further by [72] with the purpose of including information on the geochemical signature of aqueous and gaseous geofluids. In particular, the following information on the sampled manifestations was proposed to be included in the standard technical reports: (1) water temperature; (2) chemical and isotopic composition of water; (3) concentration of radionuclides; (4) gas content and composition; (5) possible presence of bubbles; (6) origin and underground residence time of groundwater.

Igarashi and Wakita [73] proposed additional guidelines, now widely adopted by the scientific community, for the statistical processing of time series of geochemical parameters. In particular, a definition of "geochemical anomaly" was proposed based on differences larger than $2 \sigma$ between the values of the measured parameters and the baseline (a standard deviation over the whole observation period) during an observation period longer than one day. This approach was adopted by the Sub-Commission on Earthquake Prediction of the International Association on Seismology and Physics of the Earth Interior (IASPEI, [6]), which underlined, among other things, that "the difference between anomalous and normal values shall be expressed quantitatively, with an explicit discussion of noise sources and signal-to-noise ratio. Negative evidence (such as failure to observe the anomaly at other sites nearer the earthquake hypocenter) should be reported and discussed". Furthermore, the Sub-Commission on Earthquake Prediction recommended that "the observed anomaly should have a relation to stress, strain, or some mechanism leading to earthquakes". The mentioned recommendations and procedures have been set up due to the extremely low amplitude of recorded signals and to the possible low signal-to-noise ratio.

In the considered scientific literature review, only a few time-series of geochemical or hydrologic parameters have been collected strictly following the recommendations and the procedures described above. Considered recorded time series have been often collected within the frame of research projects oriented to the search for possible earthquake precursors and authors sometimes published who have identified possible precursory anomalies. Although a scrutiny of all reported publications is beyond the scope of the present paper, in the following we propose a list of selected manuscripts that at least partly satisfy the requested quality criteria: Alessio et al. [46], Del Pezzo et al. [60], Allegri et al. [47], Facchini et al. [16], Ghiara et al. [54], Albarello and Martinelli [23], Di Bello et al. [51], Quattrocchi and Calcara [50], Quattrocchi et al. [39], Lapenna et al. [38], 
Colangelo et al. [52,53], Cioni et al. [28], Favara et al. [64], Plastino et al. [41], Petrini et al. [19], Dadomo et al. [41], Pierotti et al. [29,30], Camarda et al. [65], Barberio et al. [43], Gherardi and Pierotti [31], De Luca et al. [44].

\section{Possible Correlation between Epicentral Distance and Magnitude}

Further constraints on possible precursory phenomena were recently proposed by $[5,74]$. These reviews evidenced that most of the precursory signals associated with geofluids during the past seventy years have been recorded in thermal springs or in deep wells in extensional areas characterized by a relatively high heat flux $\left(>70 \mathrm{~mW} / \mathrm{m}^{2}\right)$, shallow hypocentral depth of earthquakes $(<20 \mathrm{~km})$, and at distances not exceeding $250 \mathrm{~km}$ from volcanic centers. These areas are often highly $\mathrm{CO}_{2}$ degassing, as observed by [75] (and references therein). In Figure 8, a possible correlation has been found between the distance at which the geofluids anomalies have been recorded and the magnitude of the seismic event. This correlation looks very similar to the interpolation line obtained by [74] for a database of 457 literature data collected worldwide in the past few decades. Figure 8 strongly supports the hypothesis that all the anomalies documented here are related to crustal deformation processes and indicates that the distance at which possible precursory signals have been recorded in Italy is comparable to the distances observed worldwide by [74]. The proposed relationship between the distance in kilometers from the epicentral area ( $D$, in log units) and the magnitude of the seismic event has the following form:

$$
\log D(k m)=0.28 \times M_{L}+0.25
$$

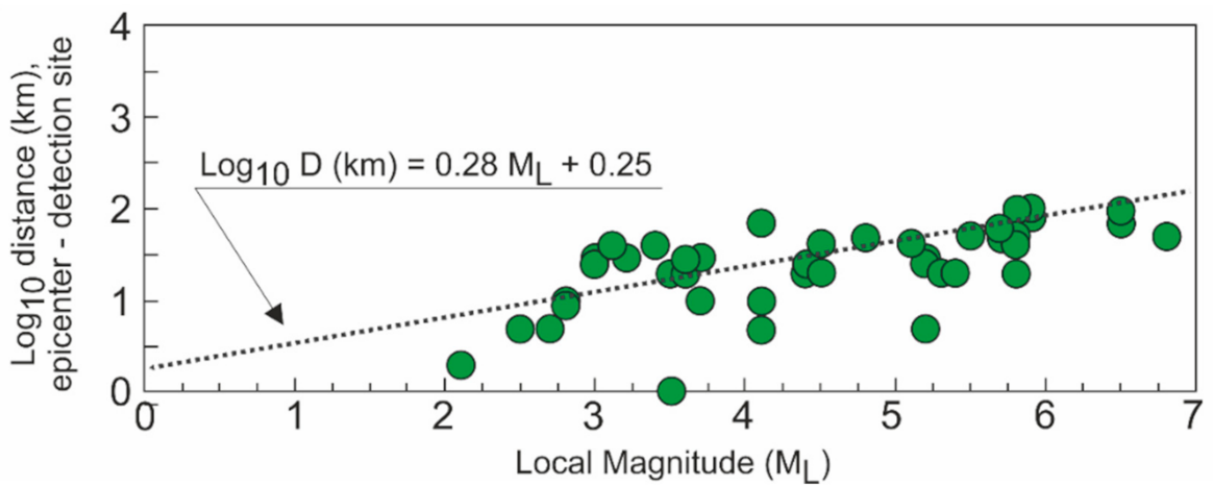

Figure 8. Distance vs, magnitude diagram for Italian geofluids anomalies considered in this work.

\section{Towards an Italian Geofluids Monitoring Network}

The idea of organizing a national network of stations capable of monitoring groundwaters and gas emissions in Italy oriented to possible earthquake forecasting has been suggested on various occasions by different researchers in recent decades (e.g., [12,76-80], and reference therein). During the same period, scientific and political institutions have not reached an agreement about the setup of a national geofluids monitoring network. As a consequence, national scientific institutions have opted to set up not a single state-wide network, but instead a number of local- to regional-scale networks, extended on areas roughly between 10,000 and $26,000 \mathrm{~km}^{2}$.

In particular, the Istituto di Geoscienze e Georisorse (IGG) of the National Research Council of Italy (CNR), Pisa, is at present operating six geochemical stations in Toscana. INGV, Rome, and INGV, Palermo, are currently operating four geochemical stations in Central Italy, in the frame of the Alto Tiberina Near Fault Observatory (TABOO; [81], and references therein). INGV, Palermo, is operating 10 geochemical stations for $\mathrm{CO}_{2}$ monitoring in Sicilia, and two hydrogeological stations in Calabria. The Istituto di Metodologie per l'Analisi Ambientale (IMAA) of CNR, Tito Scalo, is operating one geochemical station in the Tramutola municipality (Potenza province, Basilicata) jointly with GeoForschungsZen- 
trum (GFZ)-Potsdam. The University of Rome, Department of Earth Sciences, is operating two hydrogeological stations in the Abruzzo region. INGV, L'Aquila, is operating two hydrogeological stations in the mountainous massif of Gran Sasso, Abruzzo region.

To date, time series are constantly recorded and published by the relevant scientific agencies. Overall, a quite well-distributed network of monitoring stations belonging to different Institutions is at present working in Italy, but a more effective level of coordination is needed to improve the efficiency of a possible national prevention system. The setup of a few additional hydrogeological and geochemical stations could guarantee an effective coverage of the national territory within a reasonable number of years.

\section{Priority Sites for the Implementation of a Geochemical Network}

Areas characterized by possible PGA > 0.150 [8] should be considered, in principle and as a first approximation, as priority areas to set up geochemical or hydrogeological stations. Earthquakes characterized by $M_{W}>5.5$ have occurred in the past and are expected to occur over the coming decades in the areas contoured by [8]. Further details about site selection procedures for possible monitoring activities have been reported by [82]. Recent review papers $[5,74]$ have evidenced that a great majority of precursory signals recorded in geofluids in the past seventy years have been recorded in thermal springs or in deep wells in extensional areas characterized by relatively high heat flux, shallow hypocentral earthquake depth and at distances not exceeding $250 \mathrm{~km}$ from volcanic centers. These areas are often highly $\mathrm{CO}_{2}$ degassing, as observed by [75,83], among others. In Italy, such geological and geophysical features are chiefly found in Central and Southern Italy. No $\mathrm{CO}_{2}$ gas emissions exist in Northern Italy, while only Friuli Venezia Giulia could be considered as a priority area according to PGA.

The peculiar geological complexity of Italy results from the collision between the Adriatic microplate, which is being thrust westwards and northwards over the Eurasian plate beneath the Southern Alps, the flexure of the Adriatic lithosphere below the Apennines, and the westward subduction of the Ionian lithosphere below the Calabrian Arc. Northern Italy is an area of compression; the majority of peninsular Italy, south of the Po valley, and Sicilia are dominated by an asymmetric thrust belt which has compressional and extensional fronts, and active oceanic subduction [84]. Most of the more relevant earthquakes $\left(M_{W}>6\right)$ occurred along the Apennine chain and in the eastern Alpine belt, which are the youngest folded areas of the Italian peninsula (Figure 9).

The largest earthquakes $\left(M_{W}>7\right)$ occurred in Central and Southern Italy and particularly in the Calabrian arc. In Italy, the occurrence of geofluids is controlled by deep crustal discontinuities that developed over the last 5-10 My, and their physical and chemical parameters are slightly modulated by crustal strains. Geofluid emissions bring information on processes that occur primarily in the crust, marking the surface projection of visible or invisible discontinuities that control the modes of seismic release [85]. The most favorable conditions for possible earthquake precursor detection are linked to shallow depth seismicity $(<20 \mathrm{~km})$ occurring in areas characterized by relatively high heat flux and where the possible presence of geofluids at depth, particularly water and $\mathrm{CO}_{2}$, may reduce shear resistance and induce frictional sliding (e.g., [74]).

Some thermal springs could be available for monitoring activities in Northern Italy, although present-day withdrawal may reduce their suitability. The $5000 \mathrm{~m}$ deep well of Rodigo, near Goito (Mantova province), Lombardia region, and the Miano di Corniglio 1000 m deep well near Corniglio (Parma province), Emilia Romagna region, could be considered instead as suitable, priority sites for geofluids monitoring in Northern Italy. Similarly, also the sites described by [19] in the Friuli Venezia Giulia region should be monitored attentively for hydrological and geochemical precursors. 


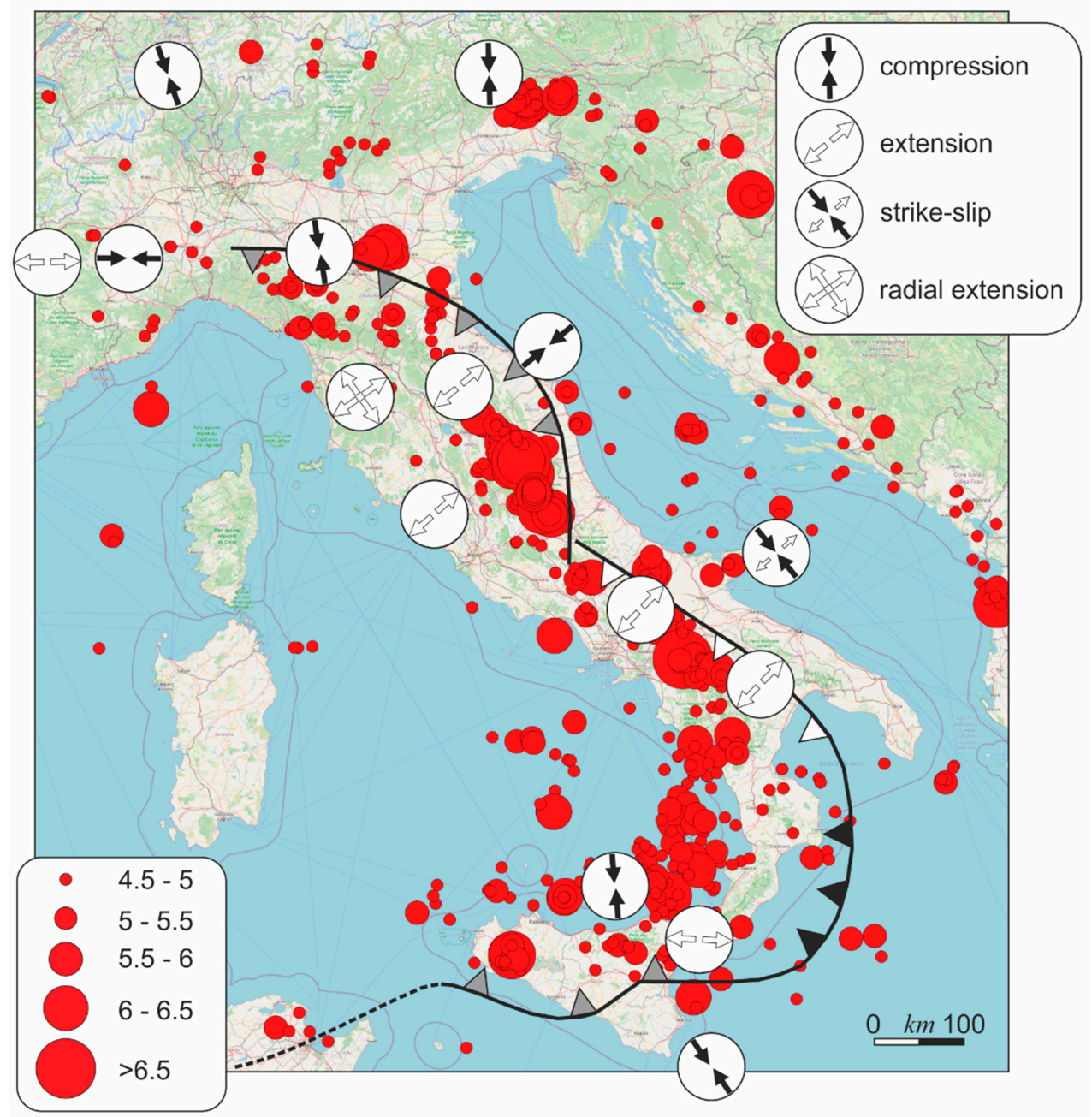

Figure 9. Seismic events (red dots) with $M_{W} \geq 4.5$ occurred in Italy from 1960 to 2021 within a radius of $600 \mathrm{~km}$ from Roma. Seismic information has been kept from the Italian earthquake catalogue CPTI15 [69] and from the Italian Seismological Instrumental and Parametric Database (ISIDe; http: / / iside.rm.ingv.it), compared with stress field in Italy (redrawn after [84]). Bold lines = structural arcs; shaded triangles = active compressional fronts; solid triangles = active oceanic subduction; open triangles $=$ front of the Plio-Pleistocene thrust, now prevalently affected by extension.

The regions of Central and Southern Italy characterized by PGA $>0.150$ should be also considered as additional, primary targeting areas. Thermal springs suitable for monitoring activities and scarcely affected by man-induced noise widely occur in most of these regions. Undisturbed $\mathrm{CO}_{2}$ gas emissions are common in Toscana, Umbria, Lazio, Campania and Sicilia regions.

As detailed in the preceding chapters, a large number of the most promising sites are already monitored by scientific institutions, and the development of a more widespread national monitoring network could now be achieved by equipping some of the currently unmonitored sites with site-specific, automatic surveying systems.

\section{Conclusions}

In the last fifty years, geofluids monitoring techniques have been successfully applied in Italy to reveal the hydrological and geochemical anomalies likely associated with crustal deformation processes that accompanied the most energetic earthquakes. This review shows that a large part of the national territory currently hosts automatic equipment capable of recording and broadcasting information about possible deformation in the crust by inspection of geofluids hydrological and geochemical features. 
Areas of priority interest for the setup of additional automatic surveying systems have been identified to promote the transition from the current operating condition, which envisages the presence of a set of small, disconnected monitoring networks, towards a single, well-coordinated national monitoring network.

Ideally, future seismic hazard reduction policies should consider the setup of a national network of local/regional automatic monitoring networks that will allow for an integrated, multidisciplinary cross-checking of different signals, including "standard" geophysical parameters (such as seismometric, GNSS, satellite and electromagnetic techniques) along with hydrological and geochemical parameters in geofluids.

Supplementary Materials: The following are available online at https:/ / www.mdpi.com/2075-1 63X/11/2/107/s1, Table S1: Water level and temperature of the Mefite d'Ansanto well (Campania region), Table S2: Water level of the E29 well (Sicilia region).

Author Contributions: Conceptualization, G.M., L.P. and F.G.; methodology, G.M., R.C., G.F., F.F., F.G., J.H., L.P.; data curation, G.M., R.C., G.F., F.F., F.G., J.H., L.P.; writing-original draft preparation, G.M., R.C., G.F., F.F., F.G., J.H., L.P.; writing-review and editing, G.M., R.C., G.F., F.F., F.G., J.H., L.P. All authors have read and agreed to the published version of the manuscript.

Funding: The Chinese Academy of Sciences Visiting Professorship partially supported Giovanni Martinelli for Senior International Scientists (2018VMA0007). The Seismic Prevention Office of the Toscana Region, Italy, financed the setup and co-finances the maintenance costs of the Toscana Geochemical Network managed by CNR-IGG Pisa, and the Radon automatic monitoring station of Gallicano, Lucca, managed by the Università di Pisa, Department of Civil and Industrial Engineering.

Institutional Review Board Statement: Not applicable.

Informed Consent Statement: Not applicable.

Data Availability Statement: All data utilized for this article are available in the section Supplementary materials.

Acknowledgments: The authors dearly thank two reviewers for their constructive comments, which have significantly contributed to improving the quality of the manuscript. Thanks are also due to the Saxon Academy of Sciences, Leipzig, to GeoForschungsZentrum, Potsdam, and to ETH, Department Erdwissenschaften, Zurich, for effective support in the sampling and analysis of fluids from thermal springs and gas emissions in Italy.

Conflicts of Interest: The authors declare no conflict of interest.

\section{References}

1. Woessner, J.; Laurentiu, D.; Giardini, D.; Crowley, H.; Cotton, F.; Grünthal, G.; Valensise, G.; Arvidsson, R.; Douglas, J. The 2013 European Seismic Hazard Model: Key components and results. Bull. Earthq. Eng. 2015, 13, 3553-3596. [CrossRef]

2. Giardini, D.; Grünthal, G.; Shedlock, K.M.; Zhang, P. The GSHAP Global Seismic Hazard Map. In International Handbook of Earthquake \& Engineering Seismology; International Geophysics Series 81 B; Lee, W., Kanamori, H., Jennings, P., Kisslinger, C., Eds.; Academic Press: Amsterdam, The Netherlands, 2003; pp. 1233-1239.

3. Jordan, T.; Chen, Y.T.; Gasparini, P.; Madariaga, R.; Main, I.; Marzocchi, W.; Papadupoulos, G.; Sobolev, G.; Yamaoka, K.; Zschau, J. Operational earthquake forecasting-State of knowledge and guidelines for utilization. Ann. Geophys. 2011, 54, 316-391.

4. Kossobokov, V.; Peresan, A.; Panza, G.F. On operational earthquake forecast and prediction problems. Seismol. Res. Lett. 2015, 86, 287-290. [CrossRef]

5. Cicerone, R.D.; Ebel, J.E.; Britton, J. A systematic compilation of earthquake precursors. Tectonophysics 2009, 476, 371-396. [CrossRef]

6. Wyss, M. Evaluation of Proposed Earthquake Precursors; American Geophysical Union: Washington, DC, USA, $1991 ;$ p. 94.

7. Martinelli, G. Previous, current, and future trends in research into earthquake precursors in geofluids. Geosciences 2020, 10, 189. [CrossRef]

8. Stucchi, M.; Meletti, C.; Montaldo, V.; Crowley, H.; Calvi, G.M.; Boschi, E. Seismic Hazard Assessment (2003-2009) for the Italian Building Code. Bull. Seismol. Soc. Am. 2011, 101, 1885-1911. [CrossRef]

9. Meletti, C.; Marzocchi, W.; D’Amico, V.; Luzi, L.; Martinelli, F.; Pace, B.; Rovida, A.; Visini, F. The new Italian Seismic Hazard model (MPS19). In American Geophysical Union, Fall Meeting 2019; \#NH23A-03, abstract; American Geophysical Union: Washington, DC, USA, 2019; Available online: https:/ / ui.adsabs.harvard.edu/abs/2019AGUFMNH23A.03M/abstract (accessed on 18 January 2021).

10. Dall'Aglio, M. Earthquake prediction by hydrogeochemical methods. Rend. Soc. Ital. Mineral. Petrol. 1976, 32, 421-436. 
11. Carapezza, M.; Nuccio, P.M.; Valenza, M. Geochemical precursors of earthquakes. In High Pressure Science and Technology; Vodar, B., Marteau, P.H., Eds.; Pergamon Press: New York, NY, USA, 1980; pp. 90-103.

12. Martinelli, G. Hydrogeologic and geochemical precursors of earthquakes: An assessment for possible applications. Boll. Geofis. Teor. Appl. 2015, 56, 83-94. [CrossRef]

13. Binda, G.; Pozzi, A.; Michetti, A.M.; Noble, P.J.; Rosen, M.R. Towards the understanding of hydrogeochemical seismic responses in karst aquifers: A retrospective meta-analysis focused on the Apennines (Italy). Minerals 2020, 10, 1058. [CrossRef]

14. De Gregorio, S.; Federico, C.; Cappuzzo, S.; Favara, R.; Giudice, G.; Gurrieri, S.; Boschi, E. Multi-parametric monitoring system of associated seismic phenomenology and unusual animal behaviour in western Piedmont. Geofluids 2012, 12, 142-149. [CrossRef]

15. De Liso, G.; Fidani, C.; Viotto, A. Stress-induced temperature variations in groundwaters of the Monferrato area (north-western Italy). Adv. Res. 2014, 2, 303-319. [CrossRef]

16. Facchini, U.; Magnoni, S.; Sordelli, C. Rodigo 1, Northern Italy: A geothermal complex for agriculture. Geothermics 1993, 22, 135-147. [CrossRef]

17. Martinelli, G. Fluidodynamical and chemical features of Radon 222 related to total gases: Implications for earthquake prediction. In Isotopic and Geochemical Precursors of Earthquakes and Volcanic Eruptions; IAEA: Vienna, Austria, 1993; pp. 48-62.

18. Balderer, W.; Leuenberger, F. Observation of fluorescence spectra of groundwater in areas of tectonic activity: Could it act as a precursor of earthquakes? In Proceedings of the International Brainstorming Session on Geochemical Precursors for Earthquakes, Kolkata, India, 11-13 September 2006; Sen, P., Das, N.K., Eds.; pp. 22-30.

19. Petrini, R.; Italiano, F.; Riggio, A.; Sleiko, F.F.; Santulin, M.; Buccianti, A.; Bonfanti, P.; Slejko, D. Coupling geochemical and geophysical signatures to constrain strain changes along thrust faults. Boll. Geofis. Teor. Appl. 2012, 53, 113-134. [CrossRef]

20. Garavaglia, M.; Braitenberg, C.; Zadro, M.; Quattrocchi, F. Radon measurements in soil and water in the seismic Friuli area. II Nuovo Cim. 1990, 22, 415-422.

21. Riggio, A.; Sancin, S. Radon measurements in Friuli (N.E. Italy and earthquakes: First results. Boll. Geofis. Teor. Appl. 2005, 46, 47-58.

22. Rossi, G.; Fabris, P.; Zuliani, D. Overpressure and fluid diffusion causing non-hydrological transient GNSS displacements. Pure Appl. Geophys. 2018, 175, 1869-1888. [CrossRef]

23. Albarello, D.; Martinelli, G. Piezometric levels as possible geodynamic indicators: Analysis of the data from a regional deep waters monitoring network in northern Italy. Geophys. Res. Lett. 1994, 21, 1955-1958. [CrossRef]

24. Martinelli, G.; Albarello, D.; Mucciarelli, M. Radon emissions from mud volcanoes in northern Italy: Possible connection in the local seismicity. Geophys. Res. Lett. 1995, 22, 1989-1992. [CrossRef]

25. Heinicke, J.; Italiano, F.; Koch, U.; Martinelli, G.; Telesca, L. Anomalous fluid emission of a deep borehole in a seismically active area of Northern Apennines (Italy). Appl. Geochem. 2010, 25, 555-571. [CrossRef]

26. Fidani, C.; Balderer, W.; Leuenberger, F. The possible influences of the 2012 modena earthquakes on the fluorescence spectra of bottled mineral water. Hydrol. Curr. Res. 2017, 8, 288. [CrossRef]

27. Heinicke, J.; Braun, T.; Burgassi, P.; Italiano, F.; Martinelli, G. Gas flow anomalies in seismogenic zones in the Upper Tiber Valley, Central Italy. Geophys. J. Int. 2006, 167, 794-806. [CrossRef]

28. Cioni, R.; Guidi, M.; Pierotti, L.; Scozzari, A. An automatic monitoring network installed in Tuscany (Italy) for studying possible geochemical precursory phenomena. Nat. Hazards Earth Syst. Sci. 2007, 7, 405-416. [CrossRef]

29. Pierotti, L.; Botti, F.; D'Intinosante, V.; Facca, G.; Gherardi, F. Anomalous $\mathrm{CO}_{2}$ content in the Gallicano thermo-mineral spring (Serchio Valley, Italy) before the 21 June 2013, Alpi Apuane earthquake $(\mathrm{M}=5.2)$. Phys. Chem. Earth 2015, 85-86, 131-140. [CrossRef]

30. Pierotti, L.; Gherardi, F.; Facca, G.; Piccardi, L.; Moratti, G. Detecting $\mathrm{CO}_{2}$ anomalies in a spring on Mt. Amiata volcano. Phys. Chem. Earth 2017, 98, 161-172. [CrossRef]

31. Gherardi, F.; Pierotti, L. The suitability of the Pieve Fosciana hydrothermal system (Italy) as a detection site for geochemical seismic precursors. Appl. Geochem. 2018, 92, 166-179. [CrossRef]

32. Makridakis, S.; Wheelwright, S.C.; Hyndman, R.J. Forecasting Methods and Applications, 3rd ed.; John Wiley and Sons: New York, NY, USA, 1998; p. 642.

33. Gutenberg, B. The energy of earthquakes. Quart. J. Geol. Soc. Lond. 1956, 112, 1-14. [CrossRef]

34. Italiano, F.; Martinelli, G.; Nuccio, P.M. Anomalies of mantle derived helium during the 1997-1998 seismic swarm of UmbriaMarche, Italy. Geophys. Res. Lett. 2001, 28, 839-842. [CrossRef]

35. Italiano, F.; Martinelli, G.; Rizzo, A. Geochemical evidence of seismogenic-induced anomalies in the dissolved gases of thermal waters: A case study of Umbria (Central Apennines, Italy) both during and after the 1997-1998 seismic swarm. Geochem. Geophys. Geosystems 2004, 5. [CrossRef]

36. Italiano, F.; Caracausi, A.; Favara, R.; Innocenzi, P.; Martinelli, G. Geochemical monitoring of cold waters during seismicity:implications for earthquake-induced modification in shallow aquifers. Terr. Atmos. Ocean. Sci. 2005, 16, 709-729. [CrossRef]

37. Caracausi, A.; Italiano, F.; Martinelli, G.; Paonita, A.; Rizzo, A. Long-term geochemical monitoring and extensive/compressive phenomena: Case study of the Umbria Region (Central Apennines, Italy). Ann. Geophys. 2005, 48, 43-53. [CrossRef]

38. Lapenna, V.; Martinelli, G.; Telesca, L. Long-range correlation analysis of earthquake-related geochemical variations recorded in Central Italy. Chaos. Solitons. Fractals. 2004, 21, 491-500. [CrossRef] 
39. Quattrocchi, F.; Pik, R.; Pizzino, L.; Guerra, M.; Scarlato, P.; Angelone, M.; Barbieri, M.; Conti, A.; Marty, B.; Sacchi, E.; et al. Geochemical changes at the Bagni di Triponzo thermal spring during the Umbria-Marche 1997-1998 seismic sequence. J. Seismol. 2000, 4, 567-587. [CrossRef]

40. Heinicke, J.; Martinelli, G.; Telesca, L. Geodynamically induced variations in the emission of $\mathrm{CO}_{2}$ gas at San Faustino (Central Apennines, Italy). Geofluids 2012, 12, 123-132. [CrossRef]

41. Dadomo, A.; Lemmi, M.; Martinelli, G.; Menichetti, M.; Telesca, L. Springwater continuous monitoring in the L'Aquila area in concomitance with the April 2009 seismic swarm in central Italy: Constraining factors to possible deep-seated fluid emissions. Chem. Geol. 2013, 339, 169-176. [CrossRef]

42. Plastino, W.; Povinec, P.P.; De Luca, G.; Doglioni, C.; Nisi, S.; Ioannucci, L.; Balata, M.; Laubenstein, M.; Bella, F.; Coccia, E. Uranium groundwater anomalies and L'Aquila earthquake, 6th April 2009 (Italy). J. Environ. Radioact. 2010, 101, 45-50. [CrossRef]

43. Barberio, M.D.; Barbieri, M.; Billi, A.; Doglioni, C.; Petitta, M. Hydrogeochemical changes before and during the 2016 AmatriceNorcia seismic sequence (central Italy). Sci. Rep. 2017, 7, 11735. [CrossRef]

44. De Luca, G.; Di Carlo, G.; Tallini, M. A record of changes in the Gran Sasso groundwater before, during and after the 2016 Amatrice earthquake, central Italy. Sci. Rep. 2018, 8, 15982. [CrossRef]

45. Martinelli, G.; Facca, G.; Genzano, N.; Gherardi, F.; Lisi, M.; Pierotti, L.; Tramutoli, V. Earthquake-related signals in Central Italy detected by hydrogeochemical and satellite techniques. Front. Earth Sci. 2020, 8, 584716. [CrossRef]

46. Alessio, M.; Allegri, L.; Bella, F.; Della Monica, G.; Ermini, A.; Improta, S.; Biagi, P.F. Studies of some precursory phenomena for the Umbria earthquake of September 19, 1979. II Nuovo Cim. 1980, 3, 589-600. [CrossRef]

47. Allegri, L.; Bella, F.; Della Monica, G.; Ermini, A.; Improta, S.; Sgrigna, V.; Biagi, P.F. Radon and tilt anomalies detected before the Irpinia (South Italy) earthquake of November 23, 1980 at great distances from the epicenter. Geophys. Res. Lett. 1983, 10, 269-272. [CrossRef]

48. Dall'Aglio, M.; Funiciello, R.; Lombardi, S.; Boschi, E.; Gasparini, C. Research activities on earthquake premonitory events-present trends in Italy. In Proceedings of the ECE/UN Seminar on Prediction of Earthquakes, Lisbon, Portugal, 14-18 November 1988; Oliveira, C.S., Ed.; Volume 2, pp. 763-778.

49. Lombardi, S.; Etiope, G.; Pinti, D.L. Variations of 222-Rn in soil gas as seismic precursor signals at Latera caldera (Central Italy). In Radon Monitoring in Radioprotection, Environmental and/or Earth Sciences; Furlan, G., Tommasino, L., Eds.; World Scientific: Singapore, 1993; pp. 418-434.

50. Quattrocchi, F.; Calcara, M. Test-sites for Earthquake Prediction Experiments within the Colli Albani Region. Phys. Chem. Earth 1998, 23, 915-920. [CrossRef]

51. Di Bello, G.; Heinicke, J.; Koch, U.; Lapenna, V.; Macchiato, M.; Martinelli, G.; Piscitelli, S. Geophysical and geochemical parameters jointly monitored in a seismic of Southern Apennines (Italy). Phys. Chem. Earth 1998, 23, 909-914. [CrossRef]

52. Colangelo, G.; Heinicke, J.; Koch, U.; Lapenna, V.; Martinelli, G.; Telesca, L. Results of gas flux records in the seismically active area of Val d'Agri (Southern Italy). Ann. Geophys. 2005, 48, 55-63. Available online: http://hdl.handle.net/2122/880 (accessed on 18 January 2021).

53. Colangelo, G.; Heinicke, J.; Lapenna, V.; Martinelli, G.; Mucciarelli, M.; Telesca, L. Investigating correlations of local seismicity with anomalous geoelectrical, hydrogeological and geochemical signals jointly recorded in Basilicata region (Southern Italy). Ann. Geophys. 2007, 50, 527-538. Available online: http://hdl.handle.net/2122/3866 (accessed on 18 January 2021).

54. Ghiara, M.R.; Stanzione, D.; Petti, C. Chemical and isotope characterizations of the deep waters of the high valley of the River Sele (Italy): Correlations between geochemical parameters and seismic activity. Ital. J. Geosci. 1994, 113, 521-537.

55. Molin, P.; Acocella, V.; Funiciello, R. Structural, seismic and hydrothermal features at the border of anactive intermittent resurgent block: Ischia Island (Italy). J. Volcanol. Geotherm. Res. 2003, 121, 65-81. [CrossRef]

56. Mongelli, F.; Harabaglia, P.; Martinelli, G.; Squarci, P.; Zito, G. Nuove misure di flusso geotermico in Italia meridionale: Possibili implicazioni sismotettoniche. In Proceedings of the Atti 14 convegno GNGTS, Roma, Italy, 23-25 October 1995; pp. 929-940.

57. Duchi, V.; Minissale, A.; Vaselli, O.; Ancillotti, M. Hydrogeochemistry of the Campania region in southern Italy. J. Volcanol. Geotherm. Res. 1995, 67, 313-328. [CrossRef]

58. Balderer, W.; Martinelli, G. Geochemistry of groundwaters and gases occurring in the 23 November, 1980 earthquake area (South Italy). Environ. Geochem. Health 1995, 16, 147-164.

59. Langelier, W.F.; Ludwig, H.F. Graphical methods for indicating the mineral character of natural waters. J. Am. Water Works Assoc. 1942, 34, 335. [CrossRef]

60. Del Pezzo, E.; Gasparini, P.; Mantovani, M.S.M.; Martini, M.; Capaldi, G.; Gomes, Y.T.; Pece, R. A case of correlation between Rn anomalies and seismic activity on a volcano (Vulcano Island, Southern Tyrrhenian Sea). Geophys. Res. Lett. 1981, 8, 962-965. [CrossRef]

61. Quattrocchi, F.; Di Stefano, G.; Pizzino, L.; Pongetti, F.; Romeo, G.; Scarlato, P.; Sciacca, U.; Urbini, G. Geochemical Monitoring System 2 prototype (GMS2) installation at the "Acqua Difesa" well, within the Etna region: First data during the 1999 volcanic crisis. J. Volcanol. Geotherm. Res. 2000, 101, 273-306. [CrossRef]

62. Immè, G.; La Delfa, S.; Lo Nigro, S.; Morelli, D.; Patanè, G. Gas Radon emission related to geodynamic activity of Mt. Etna. Ann. Geophys. 2005, 48, 65-67.

63. Cigolini, C.; Laiolo, M.; Coppola, D. Earthquake-volcano interactions detected from radon degassing at Stromboli (Italy). Earth Planet Sci. Lett. 2007, 257, 511-525. [CrossRef] 
64. Favara, R.; Grassa, F.; Madonia, P.; Valenza, M. Flow Changes and Geochemical Anomalies in Warm and Cold Springs Associated with the 1992-1994 Seismic Sequence at Pollina, Central Sicily, Italy. Pure Appl. Geophys. 2007, 164, 2411-2430. [CrossRef]

65. Camarda, M.; De Gregorio, S.; Di Martino, R.M.R.; Favara, R. Temporal and spatial correlations between soil $\mathrm{CO}_{2}$ flux and crustal stress. J. Geophys. Res. 2016, 121, 7071-7085. [CrossRef]

66. Dall'Aglio, M.; Quattrocchi, F.; Tersigni, S. Geochemical evolution of groundwater of the Iblean Foreland (Southeastern Sicily) after the December, 1990 earthquake (M=5.4). Ann. Geofis. 1995, 38, 309-329.

67. Bonfanti, P.; Carapezza, M.L.; D’Alessandro, W.; De Domenico, R.; Diliberto, I.S.; Di Liberto, R.; Giammanco, S.; Gurrieri, S.; Parello, F.; Valenza, M. Earthquake of December 13, 1990 in eastern Sicily: Some geochemical investigations. In Proceedings of the Colloquio Scientifico Sulla Protezione Sismica, Venice, Italy, 12-13 July 1993; Spagna, V., Schiavon, E., Eds.; pp. 176-184.

68. Aureli, A.; Fazio, F.; Pistorio, G. Alcuni esempi di variazioni di livello piezometrico come precursori di fenomeni sismici. In Proceedings of the Atti del $2^{\circ}$ Convegno Internazionale di Geoidrologia, Firenze, Italy, 29 November-3 December 1993; published on 1995. pp. 57-67.

69. Rovida, A.; Locati, M.; Camassi, R.; Lolli, B.; Gasperini, P. The Italian earthquake catalogue CPTI15. Bull. Earthq. Eng. 2020, 18, 2953-2984. [CrossRef]

70. Roeloffs, E.A. Hydrologic precursors to earthquakes: A review. Pure Appl. Geophys. 1988, 126, 177-209. [CrossRef]

71. Kumpel, H.-J. Pore-pressure variation as a precursory phenomenon: The need for and a list of supplementary data. Tectonophysics 1991, 193, 377-383. [CrossRef]

72. Woith, H. Radon earthquake precursor: A short review. Eur. Phys. J. Spec. Top. 2015, 224, 611-627. [CrossRef]

73. Igarashi, G.; Wakita, H. Groundwater radon anomalies associated with earthquakes. Tectonophysics 1990, 180, 237-254. [CrossRef]

74. Martinelli, G.; Tamburello, G. Geological and geophysical factors constraining the occurrence of earthquake precursors in geofluids: A review and reinterpretation. Front. Earth Sci. 2020. [CrossRef]

75. Tamburello, G.; Pondrelli, S.; Chiodini, G.; Rouwet, D. Global-scale control of extensional tectonics on $\mathrm{CO}_{2}$ Earth degassing. Nat. Commun. 2018, 9, 4608. [CrossRef] [PubMed]

76. Barbieri, M.; Boschi, E.; Dall'Aglio, M.; Fornaseri, M.; Funiciello, R.; Gasparini, C.; Lombardi, S.; Parotto, M.; Taddeucci, A.; Tonani, F. Programma di ricerca sui precursori geochimici. In Proceedings of the Atti $6^{\circ}$ Convegno Nazionale GNGTS, CNR, Roma, Italy, 14-16 December 1987; pp. 73-96.

77. Luongo, G. Un programma nazionale per la previsione dei terremoti e delle eruzioni vulcaniche. In Sono Prevedibili $i$ Terremoti e le Eruzioni Vulcaniche? Proceedings of the Atti del Convegno Scientifico di Taormina, Taormina, Italy, 13-14 April 1989; ING-CNRGNV-GNDT; Giorgetti, E., Ed.; Presidenza del Consiglio dei Ministri, Dipartimento della Protezione Civile: Roma, Italy, 1989; pp. 188-206.

78. Bella, F. Stato attuale delle ricerche sperimentali sui premonitori fisici dei terremoti in Italia. In Terremoti in Italia-Previsione e Prevenzione dei Danni; Atti dei Convegni Lincei; Accademia Nazionale dei Lincei: Roma, Italy, 1995; pp. $239-250$.

79. Calcara, M.; Quattrocchi, F.; Romeo, G.; Sciacca, U. Geochimica dei fluidi applicata alla previsione di terremoti e alla sismotettonica di aree sismiche e vulcaniche Italiane. In "Terremoti in Italia", Atti dei Convegni Lincei; Accademia Nazionale dei Lincei: Roma, Italy, 1995; pp. 330-339.

80. Doglioni, C. Discorso del Presidente dell'Istituto Nazionale di Geofisica e Vulcanologia Nella Cerimonia per il Ventennale dell'INGV. 2019. Available online: http:/ / www.ingv.it/it/discorso-del-presidente (accessed on 26 August 2020).

81. Camarda, M.; Caracausi, A.; Chiaraluce, L.; De Gregorio, S.; Favara, R. Two years of geochemical monitoring along the Alto Tiberina Fault (Italy): New inferences on fluids and seismicity in central Apennines. In Proceedings of the 20th EGU General Assembly, EGU2018, Vienna, Austria, 4-13 April 2018.

82. Martinelli, G.; Albarello, D. Main constraints for siting monitoring networks devoted to the study of earthquake related hydrogeochemical phenomena in Italy. Ann. Geofis. 1997, 40, 1505-1525.

83. Irwin, W.P.; Barnes, I. Tectonic relations of carbon dioxide discharges and earthquakes. J. Geophys. Res. 1980, 85, 3115-3121. [CrossRef]

84. Montone, P.; Amato, A.; Pondrelli, S. Active stress map of Italy. J. Geophys. Res. 1999, 104, 25595-25610. [CrossRef]

85. Vannoli, P.; Martinelli, G.; Valensise, G. The seismotectonic significance of geofluids in Italy. Front. Earth Sci. 2021. [CrossRef] 